\title{
Drought Impacts and Adaptation Strategies for Agriculture and Rural Livelihood in the Maharashtra State of India
}

\author{
Parmeshwar D. Udmale ${ }^{1, *}$, Yutaka Ichikawa ${ }^{1}$, Anthony S. Kiem ${ }^{2}$ and Sudhindra N. Panda ${ }^{3}$ \\ ${ }^{1}$ International Research Center for River Basin Environment, University of Yamanashi, Takeda 4-3-11, Kofu, Yamanashi \\ 400-8511, Japan \\ ${ }^{2}$ Centre for Water, Climate and Land Use (CWCL), School of Environmental and Life Sciences, Faculty of Science and \\ Information Technology, University of Newcastle, Callaghan, NSW 2308, Australia \\ ${ }^{3}$ Indian Department of Agriculture and Food Engineering, Indian Institute of Technology, Kharagpur, West Bengal 721- \\ 302, India
}

\begin{abstract}
Nearly one-sixth of India is defined as a Drought Prone Area, and as such recurring drought is one of the major challenges in the region. This article focuses on various drought impacts in an important state of India (i.e. Maharashtra State), which contributes about $15 \%$ of the country's gross domestic product (GDP). Drought impacts vary from region to region, but the overall issues are similar and Maharashtra State is indicative of the rest of the Drought Prone Area of the country. This article briefly reviews the major impacts of the 2012 drought on Maharashtra State's water resources, agriculture, food security, adopted adaptation and mitigation measures and also outlines scope for future research.
\end{abstract}

Keywords: Adaptation, agriculture, climate change, drought impacts, water scarcity.

\section{INTRODUCTION}

During the period from 1901 to 2010 , about $17 \%$ were drought years in India with associated severe impacts on agriculture, water resources, food security, economy and social life in the country [1]. In the decade from 2002-2012 India had three major droughts (2002, 2009 and 2012), with the 2012 drought causing $0.5 \%$ reduction in India's gross domestic product (GDP) [2], which is equivalent to US \$9 billion. About $49 \%$ of the labor force in India is dependent on agriculture as a source of living, whereas in United States of America and Australia, this figure is 0.7 and 3.6\%, respectively [3], which helps put into context the widespread hardship that a drought can cause in India. Climate scientists are predicting that conditions similar to those that led to the 2012 drought are fast developing [4]. For example, El Niño conditions are typically associated with poor southwest monsoon (June-September) rainfall in India and the Australian Bureau of Meteorology suggests that there is a 'strong possibility' (i.e. at least a 70\% chance) of El Niño conditions developing before the end of 2014 [5]. About $60 \%$ of the total cultivated area in India still relies on natural rainfall (rainfed agriculture) and hence changes to rainfall patterns are a significant threat to India's agrarian economy. A study undertaken by The Associated Chambers of Commerce and

*Address correspondence to this author at the International Research Center for River Basin Environment, University of Yamanashi, Takeda 4-3-11, Kofu, Yamanashi 400-8511, Japan;

Tel: -81-55-220-8670;

E-mails: pd.udmale@gmail.com,pd.udmale@yahoo.com
Industry of India (ASSOCHAM) calculates that if the El Niño conditions result in a rainfall deficit of just $5 \%$ of the long term average monsoon rainfall then this will result in India's GDP being reduced by about $1.75 \%$, which is equivalent to US $\$ 33$ billion and will significantly impact the availability of jobs in the unskilled sector [6].

Nearly one-sixth of India is defined as a Drought Prone Area (DPA), with recurring drought being the major challenge in the DPA. This article focuses on various drought impacts in an important state of India (i.e. Maharashtra State), which contributes about $15 \%$ of the country's gross domestic product (GDP). Drought impacts vary from region to region, but the overall issues are similar and Maharashtra State is indicative of the rest of the DPAs in India. About $40 \%$ of the Maharashtra State falls under DPA, having annual average rainfall less than $750 \mathrm{~mm}$ (29.5 in). Agriculture (e.g. rainfed cropping, livestock) are the major sources of income generation of over $64 \%$ of the state's population. Drought typically occurs in the state once every 5 years [7]. The state has experienced a moderate drought in the year 2012. During the monsoon season of 2012, the Central Maharashtra and Marathwada divisions of the state received 546 $\mathrm{mm}$ (21.5 in) and $458 \mathrm{~mm}$ (18 in) rainfall which corresponds to a $-25 \%$ and $-33 \%$ rainfall deficit, respectively, when compared with the long term average (Fig. 1). The 2012 drought caused catastrophic impacts on agriculture and rural livelihood. These impacts of 2012 drought on State's water resources, agriculture and food security, adopted adaptations and relief measures and future plans to deal with droughts are discussed in the following sections. 


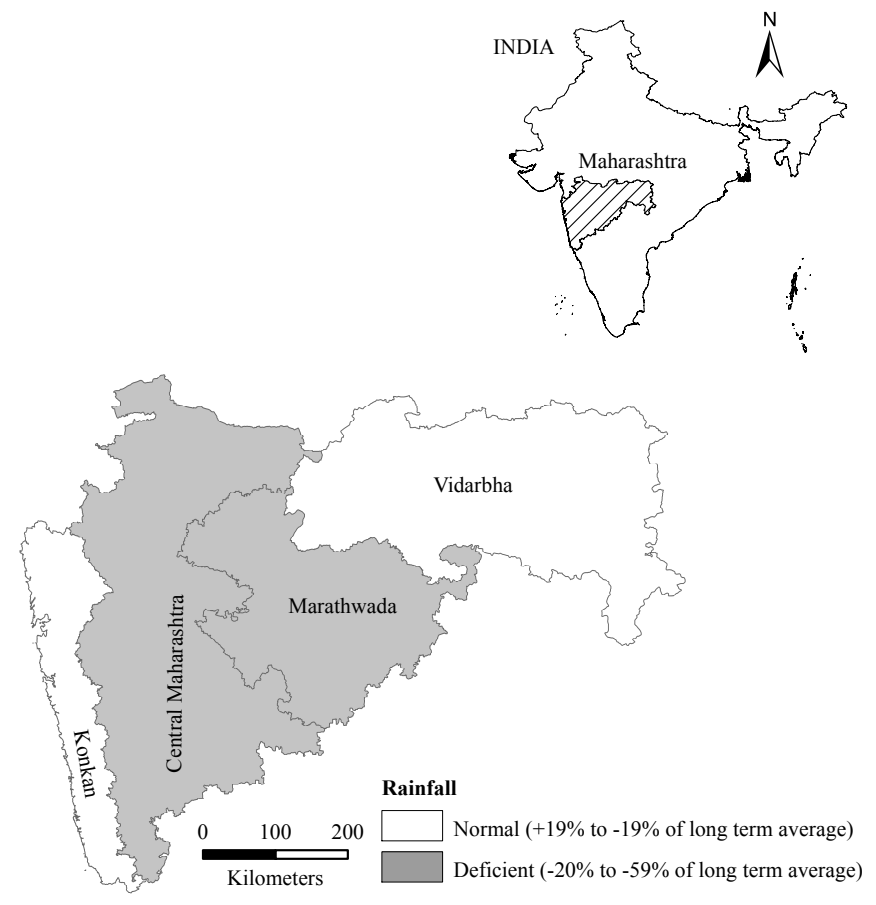

Fig. (1). The 2012 drought in Maharashtra State [8].

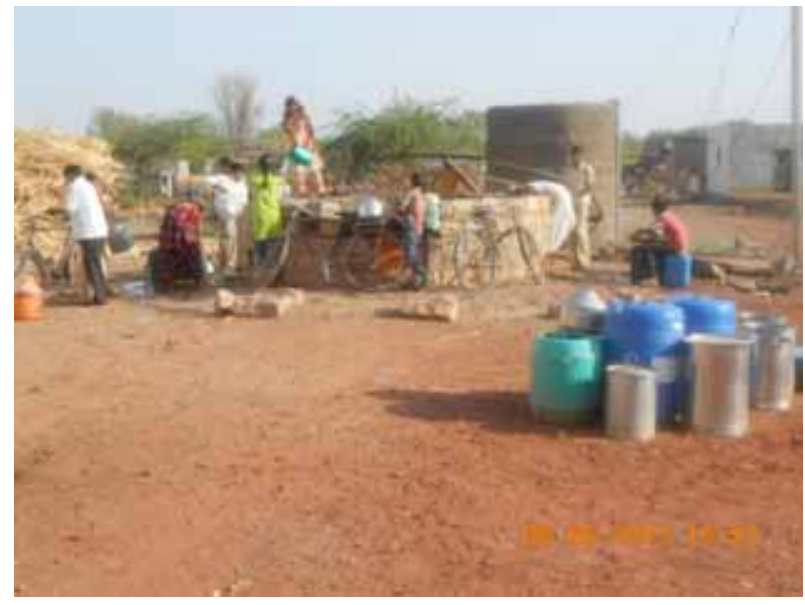

(a)

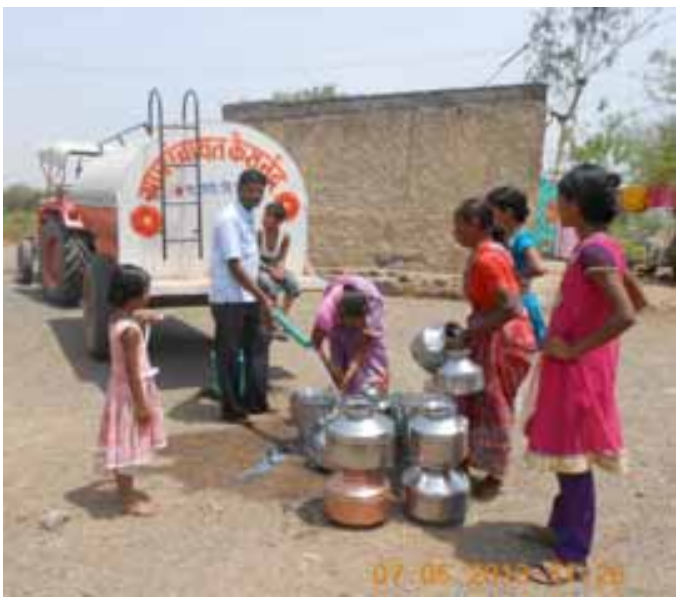

(b)

Fig. (2). Example of rural drinking water supply during a drought year: (a) tanker drops water into the well and villagers take water with the help of rope bucket, which is not only cumbersome but also makes the water dirty (Indapur Taluka, Central Maharashtra) and (b) example of private water supply tanker (Haveli Taluka, Central Maharashtra).

\section{IMPACTS OF DROUGHT ON DOMESTIC WATER SUPPLY}

About $80 \%$ of drinking water sources in the Maharashtra State are groundwater dependent. The groundwater in the state acts as buffer for long-term rainfall and surface water shortage. The average residence time of the shallow, accessible groundwater in the state is less than four years [9]. Therefore, prolonged droughts (i.e. greater than two years duration) or consecutive years of reduced monsoon rainfall severely threaten livelihoods. Insufficient monsoon rain in 2012 resulted in serious water scarcity in the Maharashtra State. Water was made available to people for consumption through private and government water supply tankers (Fig. 2). Total expenses incurred for water supply tankers, special repairs of existing water supply facilities, and construction of borewells were US $\$ 95.4$ million (US $\$ 1=$ INR 54.33 as on March 30, 2013) [10]. Recent work by the Groundwater Survey and Development Agency (GSDA) revealed that in January 2014, about 144 out of 353 talukas (subdistrict administrative divisions) showed over $1 \mathrm{~m}$ decline in groundwater level as compared to the previous 5 year average [11]. Also, water storage in state's reservoirs as on May 26, 2014, was $24 \%$ of capacity, compared with $22 \%$ in 2012 and 20\% in 2013 (Fig. 3).

A satisfactory monsoon of 2013 and some small contributions from the unseasonal showers and hailstorms in February 2014 have limited further depletion of the state's reservoir storages. However, in the face of predicted drought 


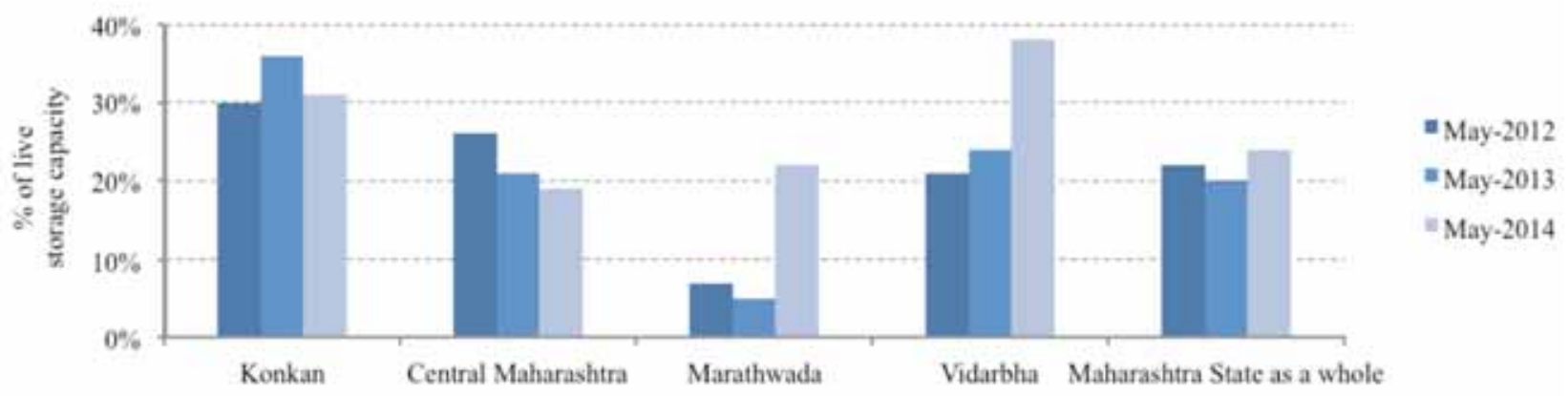

Fig. (3). Water storage in dams of Maharashtra State as a percent of live storage capacity [12].

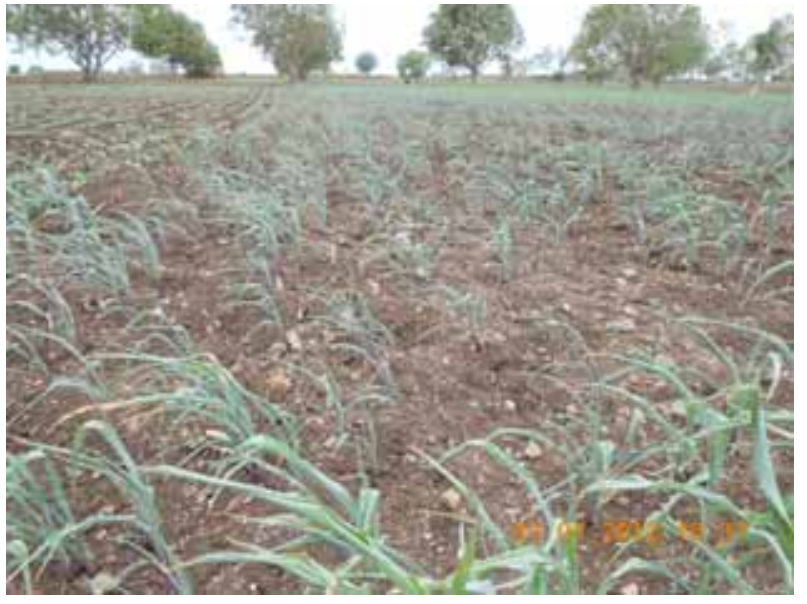

(a)

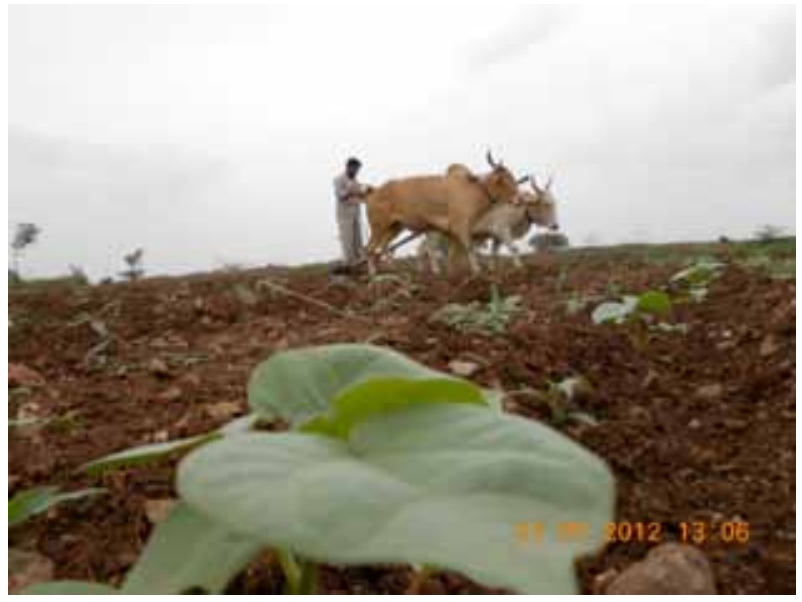

(b)

Fig. (4). Example of kharif (monsoon) crops affected due to the weak monsoon in 2012 (a) Maize crop started wilting (Karjat Taluka, Central Maharashtra) and (b) a farmer destroying cotton crops due to poor growth (Shrigonda Taluka, Central Maharashtra).

conditions before the end of 2014 the state needs to be extra cautious with using these available water resources if it is to avoid the situation that occurred during the 2012 drought. The state government has disclosed that currently about 7,896 villages are suffering under drought, out of which 3,299 villages are located in Marathwada region (Fig. 1). The state has instructed district administration to prepare an action plan for improving source of water generation, ensure proper consumption and stop wastage and to keep alternative plans ready to deal with water supply for drinking purposes until the end of July 2014. Also district administration has banned the use of water for agricultural and industrial purposes in about 15 drought hit districts and water supply tankers have been deployed in drought hit districts according to villagers demand [13]. As on May 2014 about 209 water supply tankers are in operation in Marathwada region. The situation will exacerbate if poor monsoon rainfall occurs in 2014.

\section{IMPACTS OF DROUGHT ON FOOD SECURITY}

The 2012 drought also severely affected agriculture in Maharashtra State (Fig. 4). Directorate of Economics and Statistics [14], reported about $21 \%, 5 \%$ and $18 \%$ reduction in cereals, pulses and total food grains production, respectively for the year 2012-13 as compared to the previous year.
Furthermore, it also reported $33 \%$ and $29 \%$ reduction in sugarcane and citrus fruit production respectively (Fig. 5).

Vegetable production reported $11 \%$ decrease during the 2012 when compared to the previous year. Despite the drought, milk production in the state was reported as stable (increase of about 1\%). This was largely due to the implementation of drought mitigation efforts (establishment of 441 cattle camps with expenses of US $\$ 84.5$ million until June 2013) [10] (Fig. 6). Inland fishery suffered about $16 \%$ production loss as a consequence of drought for the year 2012-13 [14]. However there was an increase in oilseeds and cotton production ( $15 \%$ and $2 \%$, respectively), and this was likely due to decreased kharif (monsoon) season crop area due to insufficient moisture conditions and farmer's anticipation of favorable returns from oilseeds and cotton production and also the government's initiative to increase its production [15]. Reduction in agricultural production due to drought subsequently caused increase in food prices in the state, and also in India as a whole. Crop failure, reduction in employment of unskilled agricultural labor and increased commodity prices severely affected the rural economy. In return, it further forced farmers to borrow money from money lenders and banks with high interest rates and this weakened financial status has further affected the social life and mental health of farmers and others in the drought affected rural communities [15-18]. 


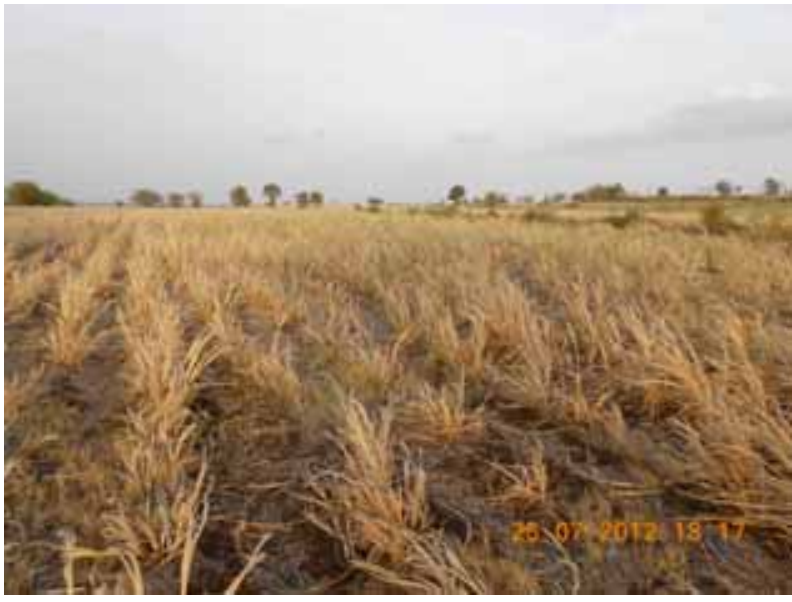

(a)

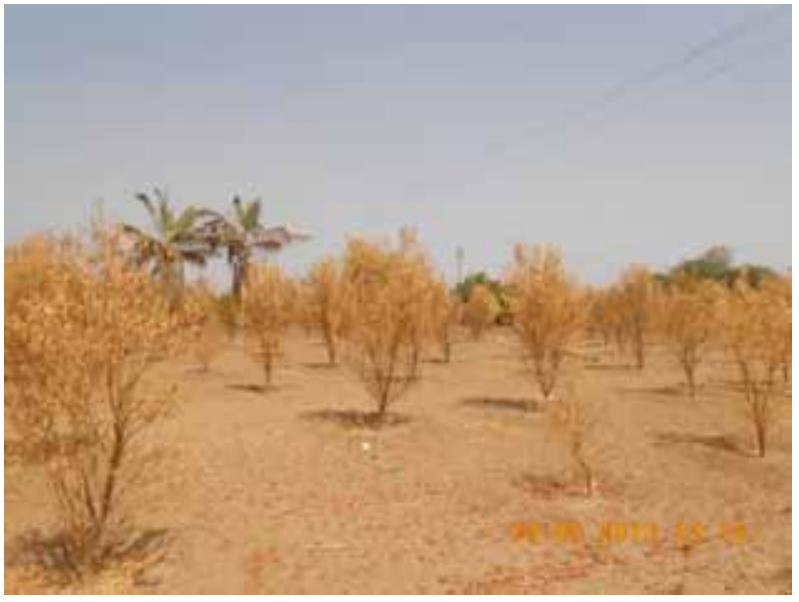

(b)

Fig. (5). (a) Sugarcane crop (Shrigonda Taluka, Central Maharashtra) and (b) Citrus fruit garden (Ahmednagar Taluka, Central Maharashtra) impacted by the 2012 drought.

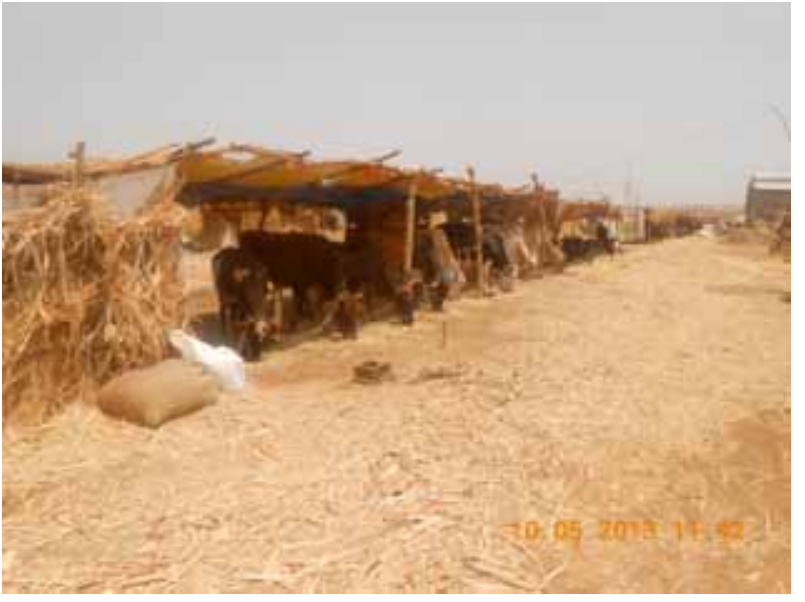

(a)

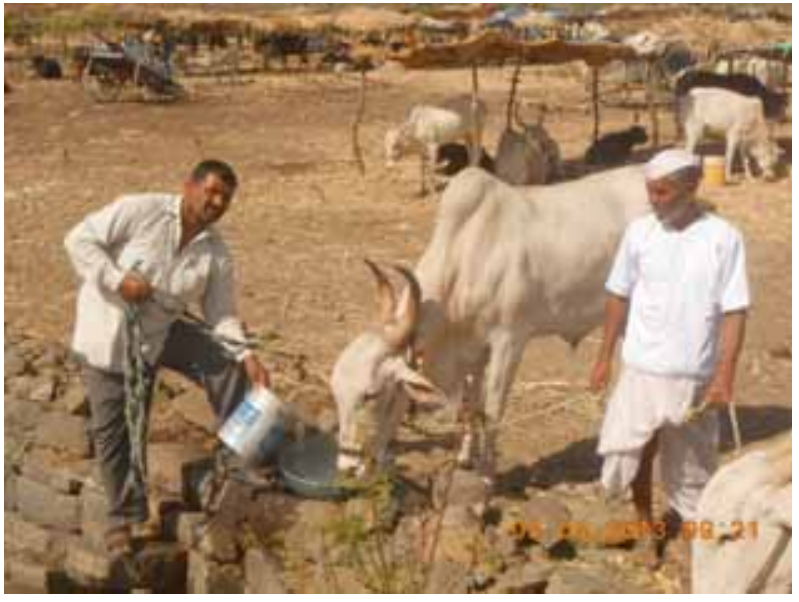

(b)

Fig. (6). Example of government funded cattle camps during drought year (a) cattle and (b) water supply in the cattle camp (Ashti Taluka, Marathwada).

\section{ADOPTED ADAPTATIONS AND DROUGHT MITIGATION MEASURES}

There are numerous drought adaptation and mitigation options available for dry land farming, most of which focus on water and soil health conservation [19]. Adoption of cropping practices such as ridge farming tillage (RFT), no tillage (NT), and stubble mulch farming tillage (SMFT) proved superior over conventional tillage (CT) so as to improve and stabilise the crop yields, conserve moisture and reverse land degradation process [20]. The use of available water during drought is very important. Most of the farmers are not equipped with water saving technologies and use flood irrigation to irrigate the crop even during drought [16], which reduces the water productivity. Only a small number of farmers adopted modern micro-irrigation technologies such as sprinkler and drip irrigation to cope up with drought (Fig. 7). The state government provides subsidies for adoption of these technologies but still the use of these practices is limited due to high initial investment, high cost involved in renewing system, understanding or maintaining the technology, and lack of irrigation water source and power supply constraints. Other adaptation options widely used are cultivation of less water intensive and drought tolerant crops, and intercropping.

Administrative mitigation measures play a very crucial role in adapting to drought. As a response to serious drought events in the Maharashtra State, the government has undertaken various relief measures, which included water supply measures such as supply of drinking water through tankers (Fig. 2), distribution of fodder in cattle camps (Fig. 6) and provision of employment (Fig. 8). In addition to this, the government has also provided agricultural loans with low interest rates, crop insurance schemes, and waived agricultural electricity bills. According to Drought Memorandum, [10], these mitigation measures (except the employment scheme) incurred a cost of approximately US \$332 million for 2012-13 drought. As mentioned above, hopelessness and mental depression due to the adverse impacts of drought is 


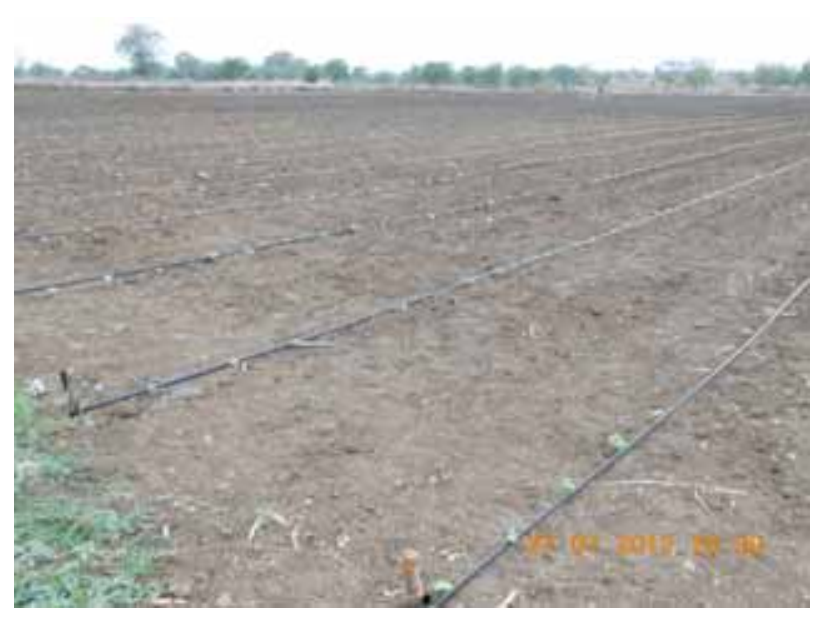

(a)

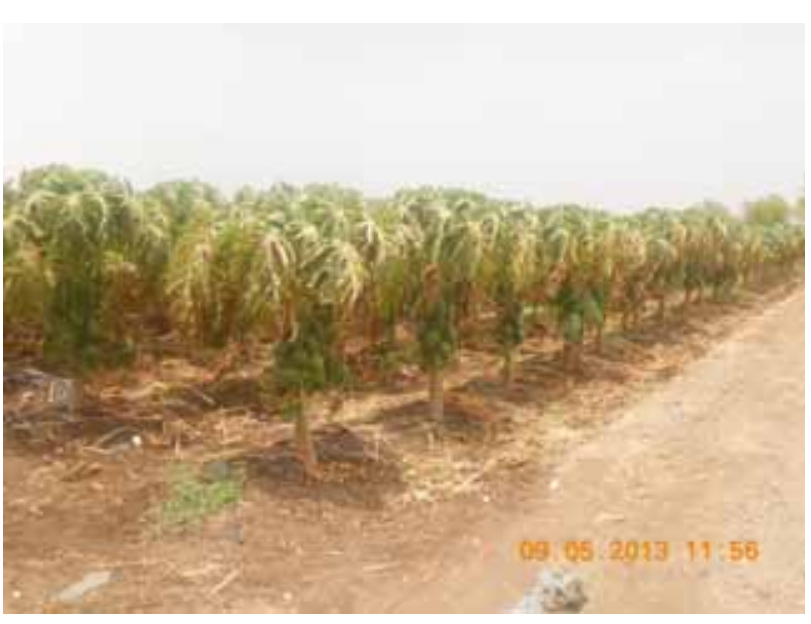

(b)

Fig. (7). Example of successful adoption of drip irrigation for (a) cotton crop during kharif 2012 (Karjat Taluka, Central Maharashtra) and (b) Papaya fruit garden during summer 2013 (Solapur Taluka, Central Maharashtra).

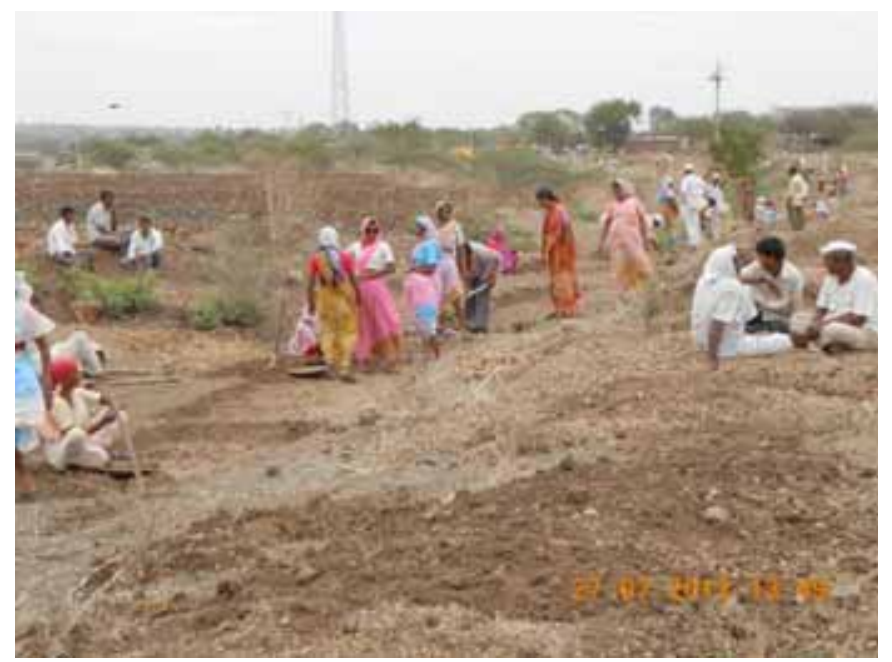

Fig. (8). Example of employment generation by government during drought under rural employment act 2005 (Karjat Taluka, Central Maharashtra).

one of the main causes behind the abnormally high rate of farmer suicide in the state and in India as a whole. In spite of huge expenses on measures to mitigate drought impacts, the numbers of farmer suicides continues to grow demonstrating a lack of social and community support in the existing drought relief packages - this is also the case in other drought prone countries [17].

\section{RECOMMENDATIONS AND SCOPE FOR FUTURE RESEARCH}

Water shortage in Maharashtra State is a major problem. Different parts of the state face water scarcity almost every year and the situation is exacerbated during drought years. To cope up with the problem of household drinking water scarcity the option of modern rainwater harvesting technologies and groundwater recharge should be promoted. Harvesting roof water for drinking purpose with economical water treatment is another option. In the case of agriculture, a detailed crop and rainwater management plan should be developed for the rain-fed regions of India. It is crucial that these plans quantify and account for uncertainties associated with climate variability and climate change.

Use of organic manure in farm (for example, composting and recovery of farm yard manure and food waste, use of green mulching, etc.) can favorably modify the physical properties of soil such as bulk density, porosity, soil moisture, temperature, water retention properties and water transmission properties and soil processes like evaporation, infiltration, runoff and soil loss for better crop growth and yield $[21,22]$. In order to improve the soil moisture holding capacity, adoption of conservation agriculture and use of organic manures should be promoted to combat drought. Improved packages of agricultural practices for major crops, keeping in view the different weather sensitive crop stages and farm operations for reducing cost of cultivation and increasing yield or net returns, should also be adopted. 
On-farm reservoir (OFR) systems, in conjunction with improved methods for forecasting dry and wet spells during crop growth season, should be developed and implemented. During wet spells, the diked crop field will contain excess rainwater and this needs to be conserved naturally in soil or groundwater reservoirs or via artificially constructed OFR systems [23].

The India Meteorological Department (IMD) monitors drought conditions over the country using a drought index based on rainfall only. Improvement in drought monitoring (spatio-temporal variability of droughts) and early warning systems for better preparedness and implementation of adaptive strategies is essential. The traditional system of drought monitoring and estimating losses by harvesting crops (for example, paisewari system in which a local agriculture officer randomly select a cropped area in a village, harvested after maturity, and crop yield is compared with previous 10 years average, then if the crop yield is less than $50 \%$ of previous 10 years average, drought year is declared for that village), needs replacement with real time remote sensing and modeling techniques for ensuring transparency and quick response. Lessons should be learned from the developed countries that are also drought prone (e.g. United States of America and Australia) regarding robust quantification of drought risk (and how it varies in space and time) and drought monitoring, forecasting and management. International research collaboration of Indian research institutes with these countries is required to increase technical capacity within India and to mitigate India's drought problems.

Knowledge dissemination of various agricultural adaptation practices (by considering the widespread anticipated droughts in coming decades) should be done via village meetings and field demonstrations with the help of local agricultural officers. According to the Indian Agriculture Ministry's crisis management plan [24], drought is not a disaster, it is a management issue. Although the state and central government has drought relief packages, improvement in management and implementation of these relief measures is necessary to mitigate the drought impacts on the community. Responses to drought in the state are re-active in terms of crisis management and poorly coordinated. Hence, the state and India as a whole, needs to change from a reactive crisis management strategy to a more proactive strategy.

\section{CONFLICT OF INTEREST}

The authors confirm that this article content has no conflict of interest.

\section{ACKNOWLEDGEMENTS}

The authors would like to express their sincere gratitude to the Ministry of Education, Culture, Sports, Science and Technology (MEXT), Japan and Global Centre of Excellence (GCOE) Program, University of Yamanashi, Japan for providing financial assistance for this study.

\section{REFERENCES}

[1] Niranjan KK, Rajeevan M, Pai DS, Srivastava K, Preethi B. On the observed variability of monsoon droughts over India. Weather Clim Extrem 2013; 1: 42-50.

[2] Manipadma J. India strives to become "drought proof". The gaurdian. 2013 Mar 12 [cited 2014 May 10]; Available from: http://www.theguardian.com/environment/2013/mar/12/indiastrives-drought-proof

[3] The World Factbook. Cent. Intell. Agency Washington, DC. 2013 [cited 2014 May 10]; Available from: https://www.cia.gov/library/publications/the-world-factbook/fields/2048.html

[4] South Asia Network on Dams Rivers and People. El Nino and Maharashtra: Lets dig the Well before we are thirsty | SANDRP on WordPress.com. 2014 [cited 2014 May 10]; Available from: http://sandrp.wordpress.com/2014/04/17/el-nino-and-maharashtradig-the-well-before-we-are-thirsty/

[5] Bureau of Meteorology Australia. ENSO Wrap-Up Current state of the Pacific and Indian Ocean.Tropical Pacific continues to warm; El Niño likely in 2014. Seas. outlooks. 2014 [cited 2014 May 21];Available from: http://www.bom.gov.au/climate/enso/

[6] ASSOCHAM. El Nino may impact India's GDP by $1.75 \%$.: ASSOCHAM study. 2014 [cited 2014 May 10]; Available from: http://www.assocham.org/prels/shownews.php?id=4490

[7] United Nations. Global Assessment Report on Disaster Risk Reduction: Risk and poverty in a changing climate. Geneva, Switzerland: 2009. Available from: http://www.preventionweb.net/english/hyogo/gar/report/index.php?id=9413\#

[8] India Metereological Deparment Pune. Monsoon 2012. Pune: 2013. Available from: http://www.imdpune.gov.in/mon-soon_report_2012.pdf

[9] Surinaidu L, Bacon CGD, Pavelic P. Agricultural groundwater management in the Upper Bhima Basin, India: current status and future scenarios. Hydrol Earth Syst Sci 2013; 17(2): 507-17.

[10] Government of Maharashtra. Drought Memorandum Drought Mitigation \& Relief Measures 2013. Available from: http://mdmu.maharashtra.gov.in/pdf/droughtmgmt/MEMORANDU M FEBRUARY 2013.pdf

[11] eSakal News. Drying dams 2014 Apr 16 [cited 2014 May 11]; Available from: http://online3.esakal.com/

[12] Government of Maharashtra. Dam storgae 2014 [cited 2014 May 26]; Available from: http://www.mahawrd.org/

[13] The Indian Express. No political bias in drought relief: CM | The Indian Express. 2014 [cited 2014 May 11]; Available from: http://indianexpress.com/article/india/india-others/no-political-biasin-drought-relief-cm/

[14] Government of Maharashtra. Economic Survey of Maharashtra2012-13 Mumbai: 2013. Available from: http://mahades.maharashtra.gov.in/files/publication/esm_2012-13_eng.pdf

[15] The Crop Site. USDA GAIN: India Oilseeds and Products UpdateAugust 2012 - Market Reports - The Crop Site 2012 [cited 2014 May 11]; Available from: http://www.thecropsite.com/repo$\mathrm{rts} / ? \mathrm{id}=1053$

[16] Udmale P, Ichikawa Y, Manandhar S, Ishidaira H, Kiem AS Farmers' perception of drought impacts, local adaptation and administrative mitigation measures in Maharashtra State, India. Int J Disas Risk Reduct 2014; 10: 250-69

[17] Kiem AS. Drought and water policy in Australia: Challenges for the future illustrated by the issues associated with water trading and climate change adaptation in the Murray-Darling Basin. Glob Environ Change 2013; 23(6): 1615-26.

[18] Kiem AS, Austin EK. Drought and the future of rural communities: Opportunities and challenges for climate change adaptation in regional Victoria. Aust Glob Environ Chang 2013; 23(5): 1307-16.

[19] Muthamilselvan M, Manian R, Kathirvel K. In situ moisture conservation techniques in dryfarming - A review Agric Rev 2006; 27(1): 67-72.

[20] Kurothe RS, Kumar G, Singh R, et al. Effect of tillage and cropping systems on runoff, soil loss and crop yields under semiarid rainfed agriculture in India. Soil Tillage Res 2014; 140: 126-34. 
[21] Bandyopadhyay KK, Hati KM, Singh R. Management Options for Improving Soil Physical Environment for Sustainable Agricultural Production : A Brief Review. J Agric Phys 2009; 9: 1-8.

[22] Debnath P, Deb P, Sen D, Pattannaik SK, Ghosh SK. Physicochemical properties and its relationship with water holding capacity of cultivated soils along altitudinal gradient in Sikkim. Int J Agric Environ Biotechnol 2012; 5(1): 99-104.
[23] Panigrahi B, Panda S, Mull R. Simulation of water harvesting potential in rainfed ricelands using water balance model. Agric Syst 2001; 69(3): 165-82.

[24] Government of India. The Crisis Management Plan Drought. 2006 26:1-41.

Received: August 23, 2014

(C) Udmale et al.; Licensee Bentham Open.

This is an open access article licensed under the terms of the Creative Commons Attribution Non-Commercial License (http://creativecommons.org/licenses/by-nc/3.0/) which permits unrestricted, non-commercial use, distribution and reproduction in any medium, provided the work is properly cited. 